University of Chicago Law School

Chicago Unbound

The United States and Human Rights Treaties: Race Relations, the Cold War, and Constitutionalism

Curtis A. Bradley

Follow this and additional works at: https://chicagounbound.uchicago.edu/journal_articles

Part of the Law Commons 


\title{
The United States and Human Rights Treaties: Race Relations, the Cold War, and Constitutionalism
}

\author{
Curtis A. Bradley*
}

\begin{abstract}
The United States prides itself on being a champion of human rights and pressures other countries to improve their human rights practices, and yet appears less willing than other nations to embrace international human rights treaties. Many commentators attribute this phenomenon to the particular historical context that existed in the late 1940s and early 1950s when human rights treaties were first being developed. These commentators especially emphasize the race relations of the time, noting that some conservatives resisted the developing human rights regime because they saw it as an effort by the federal government to extend its authority to address racial segregation and discrimination in the South. As this essay explains, the guarded and qualified U.S. relationship with human rights treaties stems not only from a particular moment in history but also is a product of more enduring, and less obviously problematic, features of the U.S. constitutional system.
\end{abstract}

1. This essay considers the history of the U.S. relationship with international human rights treaties. This relationship is sometimes described as being paradoxical or even hypocritical, in that the United States prides itself on being a champion of human rights and pressures other countries to improve their human rights practices, and yet appears less willing than other nations to embrace international human rights treaties. The United States did not begin to ratify any of the major human rights treaties until the late 1980s, and it still has not ratified a number of them, including the

* Richard A. Horvitz Professor, Duke Law School. For helpful comments and suggestions, I would like to thank Kathryn Bradley, Larry Helfer, Eric Posner and Paul Stephan. A draft of this paper was presented at the Institute of International Law at Wuhan University in China. 
International Covenant on Economic, Social and Cultural Rights, the Convention on the Elimination of All Forms of Discrimination Against Women, and the Convention on the Rights of the Child. Moreover, for the human rights treaties that it has ratified, the United States has qualified its consent to the treaties by attaching extensive reservations, understandings, and declarations, or "RUDs".

2. Many commentators attribute the complicated U.S. relationship with human rights treaties to the particular historical context that existed in the late 1940s and early 1950s when human rights treaties were first being developed. These commentators especially emphasize the race relations of the time, noting that some conservatives in the United States resisted the developing human rights regime because they saw it as an effort by the federal government to extend its authority to address racial segregation and discrimination in the South. ${ }^{1}$ While this historical claim is not inaccurate per se, it provides an incomplete picture in that it underemphasizes the Cold War fears that many people had at the time about the spread of communism abroad and the threat of totalitarianism at home - concerns that, fairly or unfairly, became linked to the developing human rights project. More importantly, an emphasis on the particular historical context of the late 1940s and early 1950 s does not explain why the complicated U.S. relationship with human rights treaties has persisted even after the end of racial segregation and after the end of the Cold War. As I will discuss, the guarded and qualified U.S. relationship to human rights treaties stems not only from a particular moment in history but also is a product of more enduring, and less obviously problematic, features of the U.S. constitutional system.

\section{U.S. Commitment to Human Rights}

3. The United States has long been committed to the idea that individuals have rights that can be asserted against their own government. In announcing their separation from the British Empire in 1776, the colonies that became the United States issued a Declaration of Independence that proclaimed that there were certain "selfevident" truths. These truths were that "all men are created equal, that they are endowed by their Creator with certain unalienable Rights, that among these are Life, Liberty and the pursuit of Happiness" [and] "[t]hat to secure these rights, Governments are instituted among Men, deriving their just powers from the consent of the governed". 2 These ideas would in turn become influential in

1 See, e.g., David M. Golove, Treaty-Making and the Nation: The Historical Foundations of the Nationalist Conception of the Treaty Power, 98 Michigan LR 1075, 1273-74 (2000); Oona A. Hathaway, Treaties' End: The Past, Present, and Future of International Lawmaking in the United States, 117 Yale LJ 1236, 1303 (2008); Louis Henkin, U.S. Ratification of Human Rights Conventions: The Ghost of Senator Bricker, 89 AJIL 341, 348 (1995).

2 The Declaration of Independence, paras. 2, 3 (U.S. 1776). 
many other countries. ${ }^{3}$ They also had continuing influence within the United States as it gradually increased its own rights protections - most dramatically when it abolished slavery during the American Civil War of the 1860s. ${ }^{4}$

4. The U.S. Constitution similarly embodies a commitment to human rights. Shortly after adopting the original Constitution in the late 1780s, the United States added ten amendments that are known as the Bill of Rights. These amendments protect the right of individuals to, among other things, speak freely, practice their religion, receive a fair trial, and receive just compensation if their property is taken by the government. Later constitutional amendments, including amendments added after the conclusion of the Civil War, added to these rights. In the modern era, Congress has supplemented the constitutional rights with a wide variety of statutory rights. Unlike the constitutional rights, modern statutory rights go beyond negative protections against government abuse and include more positive protections such as a minimum wage, unemployment insurance, and a right to social security payments upon retirement, although the United States is less expansive in the area of economic and social rights than most other Western industrialized countries. $^{5}$

5. In addition to having significant rights guarantees at home, the United States often pressures other countries to improve their human rights practices. Pursuant to a statutory directive, the U.S. State Department issues a detailed report every year that assesses and critiques other countries' human rights practices. ${ }^{6}$ The United States also sometimes imposes economic sanctions on abusive regimes, such as Burma. Occasionally it has even resorted to military force to stop human rights abuses, such as with the NATO bombing campaign against Serbia in the late 1990s. To be sure, the United States is often selective in seeking human rights reform in other countries, as it balances its commitment to human rights against other interests, such as the protection of national security and the promotion of international trade. This balancing has long been evident, for example, in the U.S. relationship with China. ${ }^{7}$ But this selectivity does not particularly distinguish the United States from other countries (although the United States may be

3 See David Armitage, The Declaration of Independence: A Global History (2007).

4 President Abraham Lincoln frequently invoked the Declaration of Independence, both before and during his presidency. See George Anastaplo, Abraham Lincoln: A Constitutional Biography (1999).

5 See Michael Ignatieff, Introduction, in American Exceptionalism and Human Rights 11 (Michael Ignatieff ed., 2005) ("U.S. rights guarantees have been employed in the service of a political tradition that has been consistently more critical of government, more insistent on individual responsibility, and more concerned to defend individual freedom than the European socialist, social democratic, or Christian democratic traditions.").

6 See U.S. Dept. of State, "Human Rights Reports", at http://www.state.gov/g/drl/rls/hrrpt/.

7 See, e.g., Robert S. Ross, China, in Richard N. Haass (ed.), Economic Sanctions and American Diplomacy 18-19 (1998). 
unique in the extent to which it focuses on the human rights practices of other nations). ${ }^{8}$

6. The U.S. emphasis on human rights was evident in the years leading up to the modern international human rights movement. In early 1941, while war was being waged in Europe and with the Great Depression still fresh in memory, President Franklin Roosevelt articulated "four essential human freedoms" that should be enjoyed by all peoples of the world: freedom of speech and expression, freedom of religion, freedom from want, and freedom from fear. ${ }^{9}$ Later, the United States led the way in establishing the United Nations, one of the express purposes of which is "to promot[e] and encourag[e] respect for human rights and for fundamental freedoms for all without distinction as to race, sex, language, or religion". ${ }^{10}$ The Charter of the United Nations also states that "[a]ll Members pledge themselves to take joint and separate action in co-operation with the Organization for the achievement of the[se] purposes". ${ }^{11}$

7. After President Roosevelt's death, his wife, Eleanor Roosevelt, served as the first chairperson of the United Nations' Commission on Human Rights. In that role, she was instrumental in helping to develop the Universal Declaration of Human Rights, a non-binding but influential resolution adopted by the United Nations General Assembly in $1948 .{ }^{12}$ The Universal Declaration, while embracing many of the civil and political rights recognized in the U.S. Constitution, also sets forth a variety of economic, social, and cultural rights. At the same time, efforts were underway in the United Nations to develop a treaty against genocide, which President Truman signed and submitted to the Senate in 1949. It was also envisioned that the Universal Declaration would be followed by a Human Rights Covenant that would embody many of the same principles articulated in the Declaration in a binding instrument. Proposals for additional human rights treaties, such as a treaty addressing the political rights of women, would soon follow.

8. This developing international human rights project became intensely controversial in the United States. As part of this controversy, there were numerous proposals introduced in the Senate in the 1950s to amend the U.S. Constitution to limit the government's treaty power. These proposals, which had the support of the American Bar Association (ABA), are known collectively as the "Bricker

8 See Anu Bradford \& Eric Posner, Universal Exceptionalism in International Law (forthcoming Harvard International Law Journal, 2010).

9 See Address of the President of the United States to Congress, January 6, 1941, 87 Cong. Rec. 44, 46-47 (1941).

10 United Nations Charter, art. 1(3).

11 Id., art. 56.

12 See Mary Ann Glendon, A World Made New: Eleanor Roosevelt and the Universal Declaration of Human Rights (2001). 
Amendment" after their chief sponsor in the Senate, John Bricker of Ohio. ${ }^{13}$ It is very difficult to amend the U.S. Constitution - it takes a two-thirds vote in both the Senate and the House of Representatives, and then approval from three-fourths of the states. None of the Bricker Amendment proposals was adopted, although one version came within a single vote of receiving two-thirds support in the Senate. ${ }^{14}$

\section{Domestic Controversies}

9. One element of the Bricker Amendment controversy concerned the race relations of the time. In the late 1940s and early 1950s, racial segregation and discrimination were common in the United States, and it was uncertain to what extent Congress had the authority to regulate these practices. Constitutional litigation was also being pursued in the courts, but it was unclear before the seminal Brown $v$. Board of Education decision in 1954 how far the courts would go in disallowing segregated public facilities, and, in any event, the equal protection guarantee of the Constitution would not address discrimination by private businesses. Some conservatives in the United States, especially in the South, were concerned that the national government would use international human rights law to achieve civil rights reform that was otherwise beyond the scope of either Congress's authority or what the Constitution mandated.

10. This concern was evident in debates over the Genocide Convention. The Convention defined genocide to include "[c]ausing ... mental harm" to members of a racial group if done with an intent to destroy the group, and conservatives objected that this phrase could be construed to reach segregation laws. For example, George Finch, the editor-in-chief of the American Journal of International Law, asked: "Can it be successfully denied that segregation laws are susceptible of being denounced as causing mental harm to all members of the group against which such laws discriminate?"15 The definition of genocide also encompassed acts done with an intent to destroy a racial group "in part", leading some critics to object that it could be construed to cover even isolated acts of racial violence. For example, Arthur Schweppe, presenting the views of an ABA subcommittee, stated critically that "it would be entirely reasonable to include race riots under the present definition, and also lynching, if engaged in with intent to destroy part of a group". ${ }^{16}$

13 See Duane Tananbaum, The Bricker Amendment Controversy: A Test of Eisenhower's Political Leadership (1988).

14 This version would have simply required congressional implementation of executive agreements and made clear that treaties that conflict with the Constitution would not be given effect.

15 The Genocide Convention: Hearings Before A Subcomm. of the Senate Comm. on Foreign Relations, 81st Cong., at 217 (1950).

16 Id. at 201. 
11. In describing the U.S. relationship with human rights treaties, some commentators focus almost exclusively on this historical connection with the unfortunate race relations of the time. ${ }^{17}$ Another important part of the historical context, however, was the Cold War backdrop. The late 1940s and early 1950s witnessed the Berlin Airlift, the establishment of a communist government in mainland China that quickly allied itself with the Soviet bloc, and the invasion of South Korea by Soviet-backed North Korean troops. ${ }^{18}$ It was also a time of high-level Soviet espionage in the United States, resulting in widely publicized criminal trials, such as the trial of Alger Hiss, a former State Department employee who was convicted of perjury relating to his espionage activities, and of Julius and Ethel Rosenberg, who were convicted of passing nuclear secrets to the Soviets. For many years, the intellectual left in the United States was skeptical that these and other individuals were in fact Soviet agents, but decoded Soviet cables and Soviet archives have now removed any reasonable doubt. ${ }^{19}$ The "McCarthyism" that resulted from the Cold War threat is now widely regarded as an overreaction, but the sense of crisis and danger at the time was nevertheless genuine.

12. In this Cold War context, there were concerns that international human rights law would develop in ways antithetical to U.S. conceptions of rights and that it would be used by the Soviet bloc in its ideological campaign against the United States. This fear appeared to be confirmed when various petitions were filed in the United Nations during this period concerning racial discrimination in the United States. ${ }^{20}$ There were also objections to the inclusion of economic, social, and cultural rights in the Universal Declaration of Human Rights, and to the proposal that such rights be included in a binding Covenant. Thus, for example, Frank Holman, President of the American Bar Association, claimed that the Declaration and proposed Covenant would "promote state socialism, if not communism, throughout the world". ${ }^{21}$ Another concern was that the developing human rights project was part of a broader pattern of empowering international institutions institutions that were thought likely to be unduly influenced by the Soviet bloc

17 See above note 1.

18 See John Lewis Gaddis, The Cold War: A New History 25-46 (2005).

19 For accounts of the extensive Soviet espionage in the United States during this period, based on material found in Soviet archives and decoded Soviet cables, see Christopher Andrew \& Vasili Mitrokhin, The Sword and the Shield: The Mitrokhin Archive and the Secret History of the KGB (1999); John Earl Haynes, Harvey Klehr, and Alexander Vassilev, Spies: The Rise and Fall of the KGB in America (2009); and John Earl Haynes \& Harvey Klehr, Venona: Decoding Soviet Espionage in America (1999).

20 See Mary L. Dudziak, Cold War Civil Rights: Race and the Image of American Democracy 43-45, 63-65 (2000); Azza Salama Layton, International Politics and Civil Rights Policies in the United States, 1941-1960, at 49-57 (2000).

21 See Natalie Hevener Kaufman, Human Rights Treaties and the Senate: A History of Opposition 68-69 (1990); see also, e.g., William Fleming, Danger to America: The Draft Covenant on Human Rights, 37 A.B.A. J. 739 (1951) (raising similar concerns). 
and, relatedly, to place too little value on U.S. conceptions of rights. One of the objections to the Genocide Convention, for example, was that it seemed to envision the eventual establishment of an international criminal court, and there was fear that such a court would not contain the same protections for the defendants as would a U.S. court. ${ }^{22}$

\section{Features of American Constitutionalism}

13. Even the addition of these Cold War considerations provides an incomplete explanation for the complicated U.S. relationship to human rights treaties. Among other things, it does not explain why this complicated relationship has continued even after the end of segregation and the end of the Cold War. To fully understand this relationship, one must also understand certain features of the U.S. constitutional system. Five features are particularly relevant: the role of the Senate in treaty-making, the federal structure of the U.S. government, the stability of the U.S. constitutional system, the strength and independence of the U.S. judiciary, and the powerful nature of the modern U.S. presidency. Viewed with these features in mind, the complicated U.S. relationship with human rights treaties is not merely a holdover from a troubled moment in U.S. history, as some commentators have suggested. ${ }^{23}$

\section{III.A. Role of the Senate}

14. One reason why it is difficult for the United States to commit to human rights treaties is that, under Article II of the Constitution, treaties require the approval of two-thirds of the Senate. The constitutional Founders adopted this requirement in part to protect regional interests in the treaty process. ${ }^{24}$ This supermajority requirement is unusual when compared with other constitutions around the world, most of which require majority legislative approval. ${ }^{25}$ The two-thirds senatorial consent requirement effectively means that a minority of senators - for example, senators who are particularly concerned about protecting U.S. sovereignty - may have an ability to block treaties supported by the majority.

15. Despite this constitutional provision, many international agreements concluded by the United States do not go through the supermajority Senate consent process. Instead, they are concluded as either "congressional-executive agreements" that involve majority approval from the full Congress, or in some instances as "sole executive agreements" that involve only unilateral executive action. For example, the

22 See Kaufman, above note 21, at 57.

23 See, e.g., id. at 2 (asserting that "current opposition to human rights treaties is a legacy of the $1950 s^{\prime \prime}$.

24 See Hathaway, above note 1, at 1283.

25 See id. at 1272, 1285. 
United States concluded the GATT and NAFTA trade agreements as congressional-executive agreements. In fact, since the late 1930s, the vast majority of international agreements concluded by the United States have been concluded as congressional-executive agreements. ${ }^{26}$

16. Although some commentators have suggested that the United States should start using the congressional-executive agreement process for concluding human rights treaties, ${ }^{27}$ it is unlikely that such a shift would be politically feasible. Human rights is one of the few subject areas for which the United States has exclusively used the Article II process. ${ }^{28}$ Moreover, these treaties have a high political salience, making it especially likely that the Senate would mobilize in this area to protect its institutional prerogatives. The Senate has already done this in the area of arms control, successfully insisting since the 1970s (through bipartisan communications to the President) that all major arms control agreements go through the supermajority Senate consent process. ${ }^{29}$

17. Furthermore, even if it were politically feasible to shift to the congressional-executive agreement process for concluding human rights treaties, such a shift would raise constitutional issues. In Missouri v. Holland, the Supreme Court held that treaties may regulate domestic matters that are otherwise beyond the scope of Congress's authority, ${ }^{30}$ but this holding probably applies only to treaties concluded through the Article II process involving supermajority Senate consent. ${ }^{31}$ One of the strongest arguments in support of the holding in Holland is that the supermajority senatorial consent process specified in Article II provides enough political process protection for federalism, such that judicial enforcement of federalism is not needed in this context. $^{32}$ That argument does not apply to congressional-executive agreements, however, since they involve the same institutional actors that are involved in enacting domestic statutes. While Congress has broad domestic authority, especially in regulating conduct that relates to interstate commerce, human rights treaties likely have

26 See Curtis A. Bradley \& Jack L. Goldsmith, Foreign Relations Law: Cases and Materials 548 (3d ed. 2009); Hathaway, above note 1, at 1288.

27 See Hathaway, above note 17.

28 See id. at 1261; Peter J. Spiro, Treaties, Executive Agreements, and Constitutional Method, 79 Texas LR 961, 1000-02 (2001).

29 See Bradley \& Goldsmith, above note 26, at 554-55, 558; Spiro, above note 28, at 996-98.

30 See 252 U.S. 416, 433-34 (1920). That case involved a federal criminal statute that implemented a treaty designed to protect migratory birds. Prior to the conclusion of the treaty, two federal district courts had held that Congress lacked the authority to regulate migratory birds within a state because the birds were part of the state's sovereign resources.

31 See, e.g., Hathaway, above note 1, at 1339; David Sloss, International Agreements and the Political Safeguards of Federalism, 55 Stanford LR 1963, 1995 (2003).

32 See, e.g., John O. McGinnis \& Michael B. Rappaport, Our Supermajority Constitution, 80 Texas LR 703, 761-62 (2002). 
provisions that exceed that broad authority, such as provisions relating to local aspects of criminal law and procedure. ${ }^{33}$

18. Nevertheless, while the supermajority consent requirement can make it difficult for the United States to conclude human rights treaties, one should not overstate the importance of this requirement. As a result of the filibuster tradition in the Senate, even ordinary legislation often requires a supermajority approval, although not quite two-thirds. ${ }^{34}$ Moreover, there is nothing inherent in the House of Representatives that makes it more receptive to international human rights law than the Senate, and, in fact, the House's more populist orientation and frequent elections might make it more sensitive to public concerns about ceding sovereignty in this area. To take one example, in response to Supreme Court decisions several years ago that cited international and foreign law in support of broad readings of U.S. constitutional rights protections, a number of bills and resolutions were proposed in Congress in opposition to this citation practice, and many of these bills and resolutions originated in the House. ${ }^{35}$

\section{III.B. Federal Structure}

19. Another relevant feature of the U.S. constitutional system is its federal structure. The United States has not only a national government but also state governments, each of which has its own legislature, executive branch, and judiciary. The U.S. Constitution was premised on the idea that the national government was being granted only limited and enumerated powers, and that some sovereignty would reside at the state level. This idea is reflected in the Tenth Amendment to the Constitution, which provides that " $[\mathrm{t}]$ he powers not delegated to the United States by the Constitution, nor prohibited by it to the States, are reserved to the States respectively, or to the people." 36 Concerns about state sovereignty are also reflected in the composition of the U.S. Senate, which consists of two senators from each state, regardless of the population of the state.

20. International human rights law presents particular challenges for the U.S. federal system. As noted, the Supreme Court held in Missouri v. Holland that treaties can regulate matters within the United States that would otherwise be reserved to the states. International human rights law in turn regulates some matters that would normally be regulated in the United States at the state and local levels, such as the

33 See Curtis A. Bradley, The Treaty Power and American Federalism, 97 Michigan LR 390, 402-05 (1998).

34 Under the Senate's rules, it takes a three-fifths' vote to overcome a filibuster, e.g., 60 out of 100 senators. See Senate Rule XXII(2).

35 See David T. Hutt \& Lisa K. Parshall, Divergent Views of the Use of International and Foreign Law: Congress and the Executive versus the Court, 33 Ohio N. U. LR 113, 12531 (2007).

36 U.S. Const. amend. X. 
administration of criminal justice and family law. In addition, unlike in many countries, treaties can be given direct effect in U.S. courts without the need for legislative implementation. The Supremacy Clause of the U.S. Constitution provides that treaties are part of the "supreme law of the land" and that state judges shall be bound by them notwithstanding anything to the contrary in state law. ${ }^{37}$ While not all treaty provisions are considered "self-executing" and thus judicially enforceable, ${ }^{38}$ some Supreme Court Justices and a California court controversially suggested in the late 1940s that the human rights provisions in the United Nations Charter were selfexecuting and thus could preempt conflicting state law. ${ }^{39}$ Moreover, the California decision looked to the Universal Declaration of Human Rights in order to give content to these provisions. ${ }^{40}$ Although vacated on appeal, that decision was frequently cited with alarm during the Bricker Amendment debates.

21. Although often connected to issues of race relations, general concerns about an erosion of federalism run throughout the mid-twentieth century debates over human rights treaties. For example, as Duane Tananbaum has noted, opponents of the Genocide Convention "feared that it would lead to UN involvement in America's internal affairs, accelerate federal encroachments on the reserved powers of the states, and nullify existing state laws". ${ }^{41}$ Similarly, an article in the Journal of the American Bar Association charged that, if the proposed Human Rights Covenant were adopted and made the supreme law of the land, "the traditional distribution of power between governments on the national and state levels would give way to a unitary state with almost all power therein exercised by the Government in Washington". 42 A particularly controversial version of the Bricker Amendment would have overturned Missouri $v$. Holland by providing that "[a] treaty shall become effective as internal law in the United States only through legislation by Congress which it could enact under its delegated powers in the absence of such a treaty." 43 Another version would have made treaties non-self-executing and thus

37 U.S. Const. art. VI, para. 2.

38 See, e.g., Medellin v. Texas, 552 U.S. 491, 508-09 (2008) (concluding that the obligation of the United States under Article 94 of the United Nations Charter to comply with decisions of the International Court of Justice to which it is a party is not self-executing); Foster v. Neilson, 27 U.S. (2 Pet.) 253, 314-15 (1829) (concluding that provision in treaty with Spain concerning land grants was not self-executing).

39 See Oyama v. California, 332 U.S. 633, 649 (1948) (Black, J., concurring, joined by Douglas, J.); id. at 673 (Murphy, J., concurring, joined by Rutledge, J.); Sei Fujii v. State, 217 P.2d 481, 487 (Cal. Dist. Ct. App. 1950), vacated, 242 P.2d 617 (Cal. 1952).

40 See Sei Fujii, 217 P.2d at 487-88.

41 Tananbaum, above note 13, at 14 .

42 Fleming, above note 21, at 798 . To respond to the federalism concerns, the U.S. government unsuccessfully attempted to have a "federal-state" clause included in the proposed Human Rights Covenant that would have limited U.S. obligations to matters within the federal government's jurisdiction. See Tananbaum, above note 13, at 17-18.

43 See Kaufman, above note 21, at 30-31. 
have required the full Congress to act before a treaty could be used to preempt state law.

\section{III.C. Constitutional Stability}

22. The stability of the U.S. constitutional system is also a relevant consideration. The United States has the oldest written constitution in the world. In the more than 220 years of operation under this constitution, the United States has maintained a democratic government in which competing political parties regularly and peacefully transfer power to each other. The important exception is of course the Civil War, but even then the national government continued to operate as a democracy under very trying conditions.

23. This stability means that human rights treaties provide less internal benefit to the United States than they do to certain other countries. Human rights treaties are non-reciprocal in that a nation's incentives to comply with them are not contingent on the behavior of other nations. Nor does a nation need to ratify a human rights treaty in order to obtain the benefits of the treaty. It can simply adopt rights protections for its citizens unilaterally. Nevertheless, nations sometimes ratify human rights treaties in order to lock in rights protections and thereby reduce the likelihood of retrenchment when there is a change in regime. This was a particular concern in some European countries, such as Germany, after World War II. ${ }^{44}$ This desire to avoid retrenchment in the face of potential regime change is simply less relevant to the United States given the stability of its constitutional system. I do not mean to suggest that the United States gains nothing from joining human rights treaties, and in fact ultimately the United States decided that it was in its national interest to find a way to do so. ${ }^{45}$ But the cost-benefit calculus for the United States is likely to be different than for other countries.

24. In light of the stability of the U.S. constitutional system, human rights treaties can in fact be seen as endangering U.S. rights guarantees. The language of these treaties reflects compromises among a diverse array of nations that have differing conceptions of rights. ${ }^{46}$ Inevitably, therefore, the rights guarantees will differ from those in the United States, and not always in ways that would be regarded in the United States as a progressive direction. The protections for freedom of speech and criminal process, for example, are higher in the United States than in many other countries. There was therefore a concern that the

44 See Andrew Moravcsik, The Origin of Human Rights Regimes: Democratic Delegation in Postwar Europe, 54 Int'l Org. 217 (2000).

45 See Curtis A. Bradley \& Jack L. Goldsmith, Treaties, Human Rights, and Conditional Consent, 149 Pennsylvania LR 399, 414 (2000).

46 See, e.g., David P. Stewart, United States Ratification of the Covenant on Civil and Political Rights: The Significance of the Reservations, Understandings, and Declarations, 42 DePaul LR 1183, 1207 (1993) ("By definition, the negotiation of multilateral treaties between states with widely differing legal systems produces compromises and ambiguities.”). 
proposed Human Rights Covenant "could be employed to justify restrictions on rights and freedoms that would otherwise be unconstitutional". ${ }^{47}$

25. This concern was heightened by language in the Missouri v. Holland decision. The Supremacy Clause of the Constitution refers to federal statutes being "made in pursuance" of the Constitution, whereas it refers to treaties as simply being "made under the authority of the United States". ${ }^{48}$ In Holland, the Court noted that "[i]t is open to question whether the authority of the United States means more than the formal acts prescribed to make the convention" 49 - that is, the approval of the president and two-thirds of the Senate. To some, the Court's "hint that there may be no other test to be applied than whether the treaty has been duly concluded indicates that the Court might hold that specific constitutional limitations in favor of individual liberty and property are not applicable to deprivations wrought by treaties". 50 This possibility was frequently noted by critics of the emerging international human rights project, ${ }^{51}$ and many versions of the Bricker Amendment included a provision making clear that treaties had to comply with the Constitution in order to operate as supreme law of the land. The need for such clarification was reduced in 1957, however, when a plurality of the Supreme Court explained that, notwithstanding Holland, "no agreement with a foreign nation can confer power on the Congress, or on any other branch of Government, which is free from the restraints of the Constitution." 52 But this decision does not entirely remove the concern that international human rights law might negatively affect how U.S. constitutional rights are interpreted. ${ }^{53}$

\section{III.D. Strong and Independent Judiciary}

26. Another relevant feature of the U.S. constitutional system is its strong and independent national judiciary. Since early in its history, the judiciary has asserted the power of judicial review, which means that it has the authority to apply the Constitution, including the rights guarantees of the Constitution, to invalidate the actions of the other branches of the government, as well as those of the states. ${ }^{54}$ The federal

47 Tananbaum, above note 13 , at 20 .

48 U.S. Const. art. VI.

49252 U.S. at 433.

50 Thomas Reed Powell, Constitutional Law in 1919-20, 19 Michigan LR 1, 13 (1920).

51 See, e.g., Frank E. Holman, Treaty Law-Making, 25 Wash. L. Rev. \& St. B. J. 382, 390 (1950).

52 Reid v. Covert, 354 U.S. 1, 16 (1957) (plurality). As the plurality explained, the reason that the Supremacy Clause does not refer to treaties being made pursuant to the Constitution was so that treaties that the United States had already entered into before the Constitution would operate as supreme federal law. See id. at 16-17.

53 See, e.g., John O. McGinnis \& Ilya Somin, Democracy and International Human Rights Law, 84 Notre Dame LR 1739, 1748-50 (2009).

54 See Marbury v. Madison, 5 U.S. (1 Cranch) 137, 177-80 (1803). 
courts are also open to hear a wide array of issues, even on sensitive questions of social policy. As Alexis de Tocqueville famously observed in his commentaries about the United States, "[t]here is hardly a political question in the United States which does not sooner or later turn into a judicial one." ${ }^{55}$ Moreover, the federal judges have lifetime appointments and thus are insulated from political pressure. The federal court system has been operating since the beginning of the country and has developed a large body of precedent, including precedent interpreting U.S. rights guarantees.

27. A contemporary illustration of the broad role of the judiciary in the United States is provided by the Supreme Court's decisions relating to the post-September 11, 2001 "war on terrorism". To date, the Court has determined the minimum procedures that must be used in evaluating which terrorist detainees can be held by the military, has asserted jurisdiction over the detention facility at the U.S. naval base at Guantanamo Bay, Cuba, and has invalidated a military trial system established by the Executive Branch. ${ }^{56}$ The Court has made clear in these decisions that, " $[w]$ hatever power the United States Constitution envisions for the Executive in its exchanges with other nations or with enemy organizations in times of conflict, it most assuredly envisions a role for all three branches when individual liberties are at stake." 57

28. The existence of a strong and independent judiciary in the United States is relevant to the U.S. relationship with human rights treaties for several reasons. First, as with the stability of the U.S. constitutional system, the existence of a strong judiciary creates less internal need for human rights treaties and related international enforcement mechanisms. The U.S. judiciary already addresses human rights protections, and it does so in a stronger way than would be possible through international institutions. Second, the existence of an independent judiciary presents more uncertainties for the United States about the effects of the treaties, since the courts are likely to exercise substantial interpretive discretion. ${ }^{58}$ As Beth Simmons has documented, common law countries tend to be more reluctant to ratify human rights treaties for precisely this reason. ${ }^{59}$ Third, because U.S. courts are generally open to hear most issues, and because the human rights treaties will inevitably use language that differs from U.S. domestic law, these treaties pose a

55 Alexis de Tocqueville, Democracy in America 270 (George Lawrence transl. 1969).

56 See Boumediene v. Bush, 553 U.S. 723 (2008); Hamdan v. Rumsfeld, 548 U.S. 557 (2006); Hamdi v. Rumsfeld, 542 U.S. 507 (2004).

57 Hamdi, 542 U.S. at 536 (plurality).

58 See, e.g., Jack L. Goldsmith, Should International Human Rights Law Trump US Domestic Law?, 1 Chicago JIL 327, 332 (2000) (“[A] domesticated ICCPR would generate enormous litigation and uncertainty, potentially changing domestic civil rights law in manifold ways.”).

59 See Beth A. Simmons, Mobilizing for Human Rights: International Law in Domestic Politics 71-77, 109 (2009). 
danger of generating substantial litigation and uncertainty. Fourth, a strong and independent domestic judiciary can increase the domestic influence of international institutions. Many human rights treaties establish interpretive bodies and call for adjudication before the International Court of Justice. The "sovereignty cost" associated with assigning authority to these international institutions increases if there is a possibility that domestic courts will adopt or defer to their decisions and interpretations. $^{60}$

29. In short, because of its legal system, ratification of human rights treaties is more costly for the United States than for some other countries. Importantly, these costs exist even when the United States supports the basic substance of the treaties, as it generally does. As Oona Hathaway explains:

Governments that anticipate that domestic actors may force them to change their behavior to abide by a treaty are likely to expect to be more constrained by their treaty commitments. This can be true even if the government supports the substance of the treaty, because it has the effect of removing discretionary power from the executive and handing it to the legislature, which is often charged with implementing the treaty, and the judiciary, which is charged with interpreting it. ${ }^{61}$

Such restraint on discretion is likely to give U.S. governmental actors pause in deciding whether and how to ratify human rights treaties.

\section{III.E. Powerful Modern Presidency}

30. Still another relevant feature of the U.S. constitutional system is the powerful nature of its modern presidency. Unlike in parliamentary systems, the executive in the United States operates separately from the legislature. Because of the ability of the executive branch to act quickly, in relative secrecy, and with a unitary voice, it is functionally the best actor to conduct U.S. foreign relations. As the United States became a major world power in the twentieth century, therefore, the power of the presidency inevitably grew. In addition, the development of the U.S. economy in this period combined with efforts to combat the Great Depression of the 1930s resulted in a large growth in administrative agencies that are within or connected to the executive branch. The need to maintain unified and secretive control over nuclear weapons and related national security programs further bolstered the executive's authority. ${ }^{62}$

60 See generally Kenneth W. Abbott \& Duncan Snidal, Hard and Soft Law in International Governance, 54 Int'l Org. 421, 437-39 (2000) (describing sovereignty costs associated with delegations of authority to international institutions).

61 Oona A. Hathaway, Why Do Countries Commit to Human Rights Treaties?, 51 J. Conflict Res. 588, 593 (2007).

62 See Garry Wills, Bomb Power: The Modern Presidency and the National Security State (2010). 
31. At the same time that international human rights law was being developed, the increased power of the presidency prompted concerns within the United States about an erosion of separation of powers. These concerns were particularly salient during the Cold War, a time when George Orwell's novel 1984 captured the fears of many about where the world was headed. Conservatives in the U.S. Senate were particularly unhappy with the concessions that President Roosevelt had unilaterally made to the Soviet Union, first in the Litvinov Assignment in the 1930s and then at the Yalta conference in $1945 .{ }^{63}$ The Truman Administration was viewed as continuing this pattern of unilateral executive authority with the Potsdam Accord in 1945, the commitment of military force to Korea in 1950, and the seizure of the nation's steel mills in 1952 in response to a threatened strike in that industry. The Universal Declaration of Human Rights was viewed by some as connected to this concern, since it was agreed to by the Executive Branch without congressional involvement.

32. Even though human rights treaties require senatorial advice and consent, they implicate concerns about the growth of presidential power for several reasons. First, by longstanding tradition, the U.S. treaty process is such that only the Executive Branch is involved in the negotiation, and the Senate is simply presented with a finished product. ${ }^{64}$ Second, many multilateral treaties, including human rights treaties, establish international institutions or are subject to interpretation by such institutions, and the U.S. representative in such institutions is typically from the Executive Branch. Third, the phenomenon of "sole executive agreements" means that there is some danger that presidents will conclude agreements without even seeking the advice and consent of the Senate, as both Roosevelt and Truman demonstrated. ${ }^{65}$

33. Much of the debate over the Bricker Amendment in fact concerned presidential power. Proponents of the Amendment were concerned that treaties might be construed as broadening the president's authority, a concern illustrated by the Truman Administration's claim that it derived authority to engage in the war in

63 See Robert A. Caro, The Years of Lyndon Johnson: Master of the Senate, at 493-94, 524 (2002). Alger Hiss, a covert Soviet agent, was part of the U.S. delegation at Yalta, where he worked on issues relating to the establishment of the United Nations. See Andrew \& Mitrokhin, above note 19, at 133. He went on to serve as the acting Secretary-General of the organizing conference of the United Nations. See id. at 134. See also G. Edward White, Alger Hiss's Looking Glass Wars: The Covert Life of a Soviet Spy (2004) (exploring Hiss's life both before and after his perjury conviction).

64 The constitutional Founders envisioned that the Senate would act as an advisory body during the treaty process, but U.S. practice did not develop that way. See Curtis A. Bradley \& Martin S. Flaherty, Executive Power Essentialism and Foreign Affairs, 102 Michigan LR 545, 62636 (2004).

65 See generally Michael D. Ramsey, Executive Agreements and the (Non)Treaty Power, 77 N.C. L. Rev. 133 (1998) (discussing the phenomenon of sole executive agreements and arguing for limitations on the president's authority to conclude and create domestic law through such agreements). 
Korea from treaties, ${ }^{66}$ and by the argument from the dissenting justices in the Youngstown steel seizure case that treaties provided support for the president's actions. ${ }^{67}$ Some versions of the Bricker Amendment were also targeted specifically at the phenomenon of sole executive agreements, and in fact it was one such version that came within a vote of passing in the Senate.

\section{Accommodating the Concerns}

34. Both the Truman Administration and the Eisenhower Administration attempted to simultaneously stay engaged with the international human rights project while addressing the various areas of concern. The Truman Administration emphasized that the Universal Declaration of Human Rights was not binding. ${ }^{68}$ It also insisted, over objections by the Soviet bloc, that the proposed Human Rights Covenant be divided into two treaties, one addressing civil and political rights and the other addressing the more controversial economic and social rights. ${ }^{69}$ In an effort to persuade the Senate to accept the proposed Genocide Convention, supporters of the Convention proposed a package of reservations, understandings, and declarations ("RUDs") to address concerns. ${ }^{70}$

35. These efforts did not appease the critics. Ultimately, as part of its effort to defeat the Bricker Amendment proposals, the Eisenhower Administration assured the Senate that the United States would not become a party to the emerging international human rights treaties. In 1953, the Secretary of State, John Foster Dulles, explained to the Senate that the Administration did "not intend to become a party to any such covenant or present it as a treaty for consideration by the Senate". ${ }^{71}$ The United States similarly informed the UN Commission on Human Rights that "the United States Government has reached the conclusion that we should not at this time become a party to any multilateral treaty such as those contemplated in the draft Covenants on Human Rights, and that we should now work toward the objectives of the [Universal] Declaration by other means." 72 Two years later, Dulles reaffirmed that "the United States will not sign or become a party to the covenants on

66 See Jane E. Stromseth, Collective Force and Constitutional Responsibility: War Powers in the Post-Cold War Era, 50 U. Miami LR 145, 153 (1995).

67 See Youngstown Sheet \& Tube Co. v. Sawyer, 343 U.S. 579, 668-70 (1952) (Vinson, C.J., dissenting).

68 See Tananbaum, above note 13, at 10-11.

69 See Kaufman, above note 21, at 76.

70 See id. at 60-62; Samantha Power, A Problem from Hell: America and the Age of Genocide 65-70 (2002).

71 Statement of Secretary of State Dulles, in Treaties and Executive Agreements: Hearings Before a Subcomm. of the Senate Comm. on the Judiciary, 83rd Cong., at 825 (1953).

7213 Marjorie M. Whiteman, Digest of International Law 668 (1968) (quoting letter dated April 3, 1953, from Secretary of State Dulles to U.S. representative on the Commission). 
human rights, the convention on the political rights of women, and certain other proposed multilateral agreements". 73

36. The Kennedy administration would later send three of the least controversial human rights treaties to the Senate for its consideration: the Supplementary Slavery Convention, the Convention on the Political Rights of Women, and the Convention Concerning the Abolition of Forced Labor. The Senate eventually gave its advice and consent to the Supplementary Slavery Convention in 1967 during the Johnson Administration, and it gave its advice and consent to the Convention on the Political Rights of Women in 1975 during the Ford Administration. The former convention simply extended a treaty to which the United States had long been a party, and, as for the latter, "supporters pointed out that accession would mandate no changes in U.S. law and would cost nothing". ${ }^{74}$ The United States did not ratify the Convention Concerning the Abolition of Forced Labor until 1991, during the Administration of the George H.W. Bush.

37. In the 1970s, President Carter, who made human rights one of the signature elements of his administration, sought to persuade the Senate to approve some of the more high-profile human rights treaties. In 1978, his Administration sent the following four human rights treaties to the Senate for its consideration: the Convention on the Elimination of All Forms of Racial Discrimination; the International Covenant on Economic, Social and Cultural Rights; the International Covenant on Civil and Political Rights; and the American Convention on Human Rights. In 1980, it added the Convention on the Elimination of All Forms of Discrimination Against Women. Importantly, the Carter Administration also included with each of these treaties a proposed package of RUDs designed to address potential senatorial objections.

38. Despite this effort, the United States did not begin to ratify any of the highprofile human rights treaties until near the end of the Reagan Administration in the late 1980s, when it finally ratified the Genocide Convention. In the 1990s, the United States proceeded to ratify the International Covenant on Civil and Political Rights (ICCPR); the Convention on the Elimination of All Forms of Racial Discrimination; and the Convention Against Torture and Other Cruel, Inhuman and Degrading Treatment or Punishment. For each of these treaties, the Senate included a package of RUDs as a condition of its advice and consent. ${ }^{75}$ The

7332 Dep't St. Bull. 820, 822 (1955); see also Caroline Pruden, Conditional Partners: Eisenhower, the United Nations, and the Search for a Permanent Peace 202 (1998) ("Eisenhower and his key advisers realized that only by disassociating the administration from the Human Rights Covenants could they hope to weaken support for the Bricker Amendment.").

74 Kaufman, above note 21, at 145.

75 For the text of the RUDs, see University of Minnesota, Human Rights Library, "U.S. Reservations, Declarations, and Understandings to Human Rights Treaties," at http://www1. umn.edu/ humanrts/usdocs/usres.html. 
United States still has not ratified other high-profile human rights treaties, such as the Convention on the Elimination of All Forms of Discrimination Against Women; the International Covenant on Economic, Social and Cultural Rights; and the Convention on the Rights of the Child, even though a large majority of nations have ratified these treaties. If and when the United States does ratify these treaties, it will almost certainly include a package of RUDs as a condition of its consent. $^{76}$

39. The RUDs can be grouped into six categories, each of which has a connection to the constitutional features discussed above. First, there are a few provisions designed to avoid a conflict with U.S. rights guarantees. An illustration of this type of provision is the reservation that the United States attached to its ratification of the ICCPR concerning restrictions on speech. Article 20 of the ICCPR requires that nations prohibit "propaganda for war", as well as "[a]ny advocacy of national, racial or religious hatred that constitutes incitement to discrimination, hostility or violence". Depending on how this article is construed, it might conflict with free speech rights under the U.S. Constitution. ${ }^{77}$ As a result, the United States attached a reservation to its ratification of the ICCPR stating that "Article 20 does not authorize or require legislation or other action by the United States that would restrict the right of free speech and association protected by the Constitution and laws of the United States".

40. Second, there are provisions designed to clarify particular treaty terms or announce how the United States will construe them, which are designed in part to reduce the possibility that courts will interpret the terms in unintended ways. In ratifying the Genocide Convention, for example, the United States included an "understanding" stating that "the term 'mental harm' in Article II(b) means permanent impairment of mental faculties through drugs, torture or similar techniques". This understanding addresses a concern, first raised in the 1950s, that the Convention's reference to mental harm could be interpreted to extend the Convention's reach to mere acts of discrimination. Another example of an interpretive understanding concerned Articles 2(1) and 26 of the ICCPR, which prohibit discrimination not only on the basis of "race, colour, sex, language, religion, political or other opinion, national or social origin, property, [and] birth", but also on the

76 See, e.g., Luisa Blanchfield, CRS Report for Congress: The Convention on the Elimination of All Forms of Discrimination Against Women: Congressional Issues, at CRS-4 (Dec. 14, 2006) (noting that the Clinton Administration included a package of RUDs when submitting the Convention on the Elimination of All Forms of Discrimination Against Women to the Senate); Luisa Blanchfield, CRS Report for Congress: The United Nations Convention on the Rights of the Child: Background and Policy Issues, at 6 (April 1, 2009) (noting that, when the Clinton Administration contemplated submitting the Convention on the Rights of the Child to the Senate, it planned to include a package of proposed RUDs).

77 See Frederick Schauer, The Exceptional First Amendment, in American Exceptionalism and Human Rights, above note 5, at 36. 
basis of any "other status". The United States attached an understanding to its ratification of the ICCPR stating that this open-ended prohibition on discrimination did not preclude legal distinctions between persons "when such distinctions are, at minimum, rationally related to a legitimate governmental objective".

41. Third, the United States has generally included "non-self-execution" declarations with its ratification of human rights treaties. ${ }^{78}$ These declarations are designed to prevent the treaties from being enforceable in U.S. courts in the absence of implementing legislation, thereby leaving to Congress the task of making any necessary changes to U.S. law. As Jack Goldsmith and I have explained, the U.S. treatymakers have justified these declarations on several grounds:

First, they believe that, taking into account the substantive reservations and interpretive conditions, U.S. domestic laws and remedies are sufficient to meet U.S. obligations under human rights treaties. There is thus no additional need, in their view, for domestic implementation. Second, there is concern that the treaty terms, although similar in substance to U.S. law, are not identical in wording and thus might have a destabilizing effect on domestic rights protections if considered self-executing. Third, there is disagreement about which treaty terms, if any, would be self-executing. The declaration is intended to provide certainty about this issue in advance of litigation. Finally, the treatymakers believe that if there is to be a change in the scope of domestic rights protections, it should be done by legislation with the participation of the House of Representatives. ${ }^{79}$

42. By avoiding the danger that courts will interpret the treaty provisions differently than intended by the political branches, or in a way that will create uncertainty about domestic rights guarantees, these declarations reduce the domestic costs of the treaties to the United States, making them easier to ratify. While the declarations have generated academic controversy, the courts have consistently deferred to them. ${ }^{80}$

43. Fourth, when consenting to human rights treaties, the U.S. Senate has generally issued "federalism understandings". These understandings state that the federal government shall implement the treaty "to the extent that it exercises legislative and judicial jurisdiction over the matters covered by the Convention and otherwise by the state and local governments". In supporting the adoption of this understanding for the ICCPR, the George H.W. Bush Administration explained that the understanding "serves to emphasize domestically that there is no intent to alter the constitutional balance of authority between the State and Federal

78 The United States did not include such a declaration when it ratified the Genocide Convention, but the Senate did declare that the President was not to deposit the U.S. instrument of ratification until after Congress had enacted implementing legislation for the Convention. See Bradley \& Goldsmith, above note 45, at 419 n.97.

79 Id. at 420 n.97.

80 See Bradley \& Goldsmith, above note 26, at 521. 
governments or to use the provisions of the Covenant to 'federalize' matters now within the competence of the States". ${ }^{81}$ These understandings are not intended to alter U.S. obligations under the treaties. Rather, as David Stewart (a former State Department attorney) notes, they "concern[] the steps to be taken domestically by the respective federal and state authorities". ${ }^{82}$

44. Fifth, like a number of other countries, the United States has reserved out of "ICJ Clauses" in the human rights treaties, whereby the International Court of Justice would have jurisdiction to hear disputes arising between nations under the treaties. For example, the United States attached a reservation to its ratification of the Genocide Convention stating that, "before any dispute to which the United States is a party may be submitted to the jurisdiction of the International Court of Justice under this article, the specific consent of the United States is required in each case". Concerns in the United States about ICJ jurisdiction, evident in the early 1950s, have grown over time, with the ICJ's exercise of jurisdiction in the Nicaragua case in the 1980s (concerning U.S. military activities) and, more recently, with the ICJ's decisions in several various death penalty cases involving U.S. obligations under the Vienna Convention on Consular Relations. ${ }^{83}$

45. Finally, a few provisions decline to consent to particular treaty terms for policy reasons. An illustration is the reservation that the United States attached to its ratification of the ICCPR concerning the juvenile death penalty. One of the provisions in Article 6 of the ICCPR disallows the imposition of the death penalty for crimes committed by persons below eighteen years of age. Until fairly recently, some states in the United States allowed for the execution of individuals who committed murder if they were at least sixteen years old at the time of the offense. ${ }^{84}$ There are significant debates within the United States concerning the death penalty, and the United States has consistently maintained that it wants to address the issue through the normal democratic process rather than through international law. As a result, the United States attached a reservation to its ratification of the ICCPR stating that it was not agreeing to the ban on the juvenile death penalty. The United States also

81 Report of the Committee on Foreign Relations, International Covenant on Civil and Political Rights, S. Exec. Rep. 103-23, at 18 (1992).

82 Stewart, above note 46, at 1202.

83 In response to the ICJ's assertion of jurisdiction in the Nicaragua case, the United States withdrew its acceptance of the ICJ's compulsory jurisdiction. In response to the Vienna Convention cases, the United States withdrew from an optional protocol to the Vienna Convention that gave the ICJ jurisdiction over disputes arising under the Convention.

84 The U.S. Supreme Court held in 2005 that the execution of juvenile offenders violates the Eighth Amendment to the U.S. Constitution, which prohibits the infliction of "cruel and unusual punishments". See Roper v. Simmons, 543 U.S. 551 (2005). In its decision, the Court cited provisions in human rights treaties that disallowed the juvenile death penalty and noted that "[t]he opinion of the world community, while not controlling our outcome, does provide respected and significant confirmation for our own conclusions". Id. at 576-77. 
stated when ratifying the Torture Convention that "it is the understanding of the United States that international law does not prohibit the death penalty, and does not consider this Convention to restrict or prohibit the United States from applying the death penalty consistent with the Fifth, Eighth and/or Fourteenth Amendments to the Constitution of the United States".

\section{Empty Symbolism or Lawyerly Care?}

46. Critics contend that, as a result of the RUDs, the U.S. ratification of human rights treaties is merely empty symbolism. As Professor Henkin explains, " $[\mathrm{b}] \mathrm{y}$ adhering to human rights conventions subject to these reservations, the United States, it is charged, is pretending to assume international obligations but in fact is undertaking nothing." ${ }^{85}$ In its strongest form, the charge is that the U.S. relationship with human rights treaties is disingenuous or hypocritical. ${ }^{86}$

47. There are a number of problems with this charge. ${ }^{87}$ Even with the RUDs, the United States has bound itself to the vast majority of the provisions in the treaties it has ratified. In addition, it has enacted domestic civil, criminal, and immigration laws to implement the Genocide and Torture Conventions. ${ }^{88}$ Although it has not enacted legislation to implement the ICCPR or the Race Convention, that is because it has determined that its existing constitutional and statutory law already satisfies the requirements of those Conventions, once the RUDs are taken into account. Importantly, critics who complain about the lack of U.S. implementing legislation do not typically show that existing law is inconsistent with the treaties. It is also worth noting that many other nations, including a number of other liberal democracies, have similarly not made the ICCPR part of their domestic law. ${ }^{89}$ In addition, even when the United States is relying on existing legal

85 Henkin, above note 1, at 344; see also, e.g., Ignatieff, above note 5, at 6 ("[W] ith a few exceptions, American ratification renders U.S. participation in international human rights symbolic, since adopting treaties does not actually improve the statutory rights protections of U.S. citizens in domestic law.”); Kaufman, above note 21, at 197 (“[T]he package of attachments [to human rights treaties] makes a mockery of the international human rights consensus reflected in the treaties."); Power, above note 70, at 16 ("These interpretations of and disclaimers about the genocide convention had the effect of immunizing the United States from being charged with genocide but in so doing they also rendered the U.S. ratification a symbolic act.").

86 See, e.g., Harold Hongju Koh, On American Exceptionalism, 55 Stanford LR 1479, 148687 (2003).

87 Some of the discussion below is drawn from Bradley \& Goldsmith, above note 45, at 456-67.

88 See 18 U.S.C. $\$ 1091$ (genocide); 18 U.S.C. $\$ 2340$ A (torture); 8 U.S.C. $\$ 1231$ note (immigration).

89 See Christopher Harland, The Status of the International Covenant on Civil and Political Rights (ICCPR) in the Domestic Law of State Parties: An Initial Global Survey Through UN Human Rights Committee Documents, 22 Human Rights Q. 187, 193 (2000). 
protections to satisfy its obligations, it is still assuming an international legal obligation not to retreat from these protections. The United States also has opened itself to comment and criticism from the international committees that administer these treaties. Consistent with the latter obligation, the United States has filed a number of reports with the various committees and has appeared before them to defend its practices.

48. Furthermore, the United States is hardly alone in attaching qualifications to its consent to the human rights treaties. Approximately a third of the parties to the ICCPR, for example, have qualified their consent with reservations, understandings, and declarations. ${ }^{90}$ Moreover, empirical assessments have shown that liberal democracies, and common law countries in particular, tend to attach the most reservations to human rights treaties. ${ }^{91}$ Nor do the non-self-execution declarations reduce the binding effect of the treaties on the United States under international law. Instead, they relate only to how the United States will implement the treaties internally. Moreover, in many countries, treaties, including human rights treaties, are never self-executing. ${ }^{92}$ Finally, the U.S. treaty practice, which involves conditional consent to some treaties and non-ratification of others, does not involve any obvious hypocrisy. As Jack Goldsmith has noted, the charge of hypocrisy "is too casually made", since the United States generally does not insist that other nations comply with human rights norms that the United States has not accepted. ${ }^{93}$

49. It is true that the United States is in limited company in having failed to ratify certain of the human rights treaties. A particularly dramatic example is the Convention on the Rights of the Child, which has been ratified by all the countries in the world (albeit often with reservations) except for the United States and Somalia. ${ }^{94}$ This treaty, however, raises significant federalism concerns for the United States, since it addresses subjects that have long been regulated in the United States primarily at the state and local levels. As David Stewart explains:

90 See Yogesh Tyagi, The Conflict of Law and Policy on Reservations to Human Rights Treaties, 71 BYBIL 181, 187 n.18 (2000).

91 See Simmons, above note 59, at 102; Jack L. Goldsmith, The Unexceptional U.S. Human Rights RUDs, 3 Univ. St. Thomas LJ 311, 314 (2005); Eric Neumayer, Qualified Ratification: Explaining Reservations to International Human Rights Treaties, 36 J. Legal Stud. 397, 420 (2007).

92 See Duncan B. Hollis, A Comparative Approach to Treaty Law and Practice, in National Treaty Law and Practice 1, 40-47 (2005).

93 Jack Goldsmith, International Human Rights Law \& the United States Double Standard, 1 Green Bag 2d 365, 371 (1998).

94 The United States has, however, ratified two optional protocols to the Convention, one relating to the involvement of children in armed conflict, and the other relating to the sale of children, child prostitution, and child pornography. For each protocol, the United States included an understanding making clear that it was not assuming any obligations under the Convention on the Rights of the Child. 
To a much greater extent than other human rights treaties recently endorsed by the Senate, this Convention addresses areas traditionally considered to be primarily or exclusive within the province of state and local authority, such as measures for child health, development and protection, custody and visitation, adoption and foster care, and education and welfare. ${ }^{95}$

50. The vagueness of some of the terms of this Convention also has generated concerns in the United States, given its strong and independent judiciary. For example, the treaty refers to various children's rights, such as rights of privacy and association, without specifying whether such rights apply only against the state or also against parents. If the latter, there would be a significant danger that it could be applied in a way that would interfere with the traditional parent-child relationship. ${ }^{96}$

51. While one can of course criticize aspects of the U.S. treaty practice on policy grounds, there is nothing about it that is inherently disrespectful of international law, as some critics have contended. Indeed, in some ways this practice actually shows more respect for the human rights treaties than the practices of many other nations. The United States carefully assesses each treaty and determines which provisions it can legally and politically accept, and it attempts to avoid making commitments that it will have difficulty honoring. The United States exercises this care when ratifying human rights treaties precisely because, unlike some countries, it does not treat such ratification as a merely symbolic act. As Senator Moynihan explained in urging ratification of the ICCPR with the package of RUDs, the United States "has undertaken a meticulous examination of U.S. practice to insure that the United States will in fact comply with the obligations that it is assuming", which "can certainly be viewed as an indication of the seriousness with which the obligations are regarded rather than as an expression of disdain for the obligations". 97 While the United States has also resisted giving the human rights treaties direct effect under its domestic law, this does not distinguish it from many other nations, and there is no obligation under international law to make treaties selfexecuting. Nor is the United States obligated to change its domestic law after ratifying a human rights treaty if its existing law is already in compliance with the treaty.

95 David P. Stewart, Ratification of the Convention on the Rights of the Child, 5 Geo. J. on Fighting Poverty 161, 176 (1998).

96 See id. at 173-76. The United States is also one of a handful of countries that has not ratified the Convention on the Elimination of All Forms of Discrimination Against Women (CEDAW). The current Secretary of State, Hilary Clinton, has stated that " $t \mathrm{t}] \mathrm{he}$ Obama Administration will continue to work for the ratification of CEDAW." Hilary Rodham Clinton, Remarks at the UN Commission on the Status of Women (Mar. 12, 2010), at http://www.state.gov/secretary/rm/2010/03/138320.htm. It is not clear, however, when the Administration will seek the Senate's advice and consent. If the United States does ratify this Convention, it seems likely that it will include a package of RUDs with its ratification.

97138 Cong. Rec. S4783 (daily ed. Apr. 2, 1992). 


\section{Conclusion}

52. The complicated U.S. relationship with human rights treaties cannot be dismissed as a mere holdover from a troubled moment in history. Rather, this relationship stems in part from more enduring features of the U.S. constitutional system. These features help to explain, among other things, the variety of RUDs that the United States has attached (and presumably will continue to attach) to its ratification of human rights treaties. While there has been extensive academic criticism of the RUDs, it is important to keep in mind that they have had bipartisan support in both the Executive Branch and the Senate, and that they helped make U.S. ratification of human rights treaties politically feasible. Moreover, even with the RUDs, the United States has bound itself to the vast majority of provisions in the treaties it has ratified, and it has subjected itself to international scrutiny and monitoring. The United States also has extensive human rights protections in its domestic law, and a judiciary willing and able to enforce them. 